\title{
The Promotion of Social Awakening through the Speech of Lewis Richardson: A Metaphorical Lens that is Echoed Today
}

\author{
Suha Mohammed \\ Regent University, Doctoral student \\ 1000 Regent University Drive \\ Virginia Beach, Virginia \\ U.S.A.
}

\begin{abstract}
This analysis will illustrate how a journey through the lens of metaphorical criticism can openly display the hardships, life, and reality of past African American voices, as their stories echo through the rhetor, Lewis Richardson. An examination of a striking speech that speaks volumes, recited by Lewis Richardson, will unravel the depth in imagery, interpretation, and symbolism from an application of a metaphorical critical lens that tells a story that just keeps getting louder and louder as it grows unheard. "When metaphor is seen as a way of knowing the world, it plays a particular role in argumentation" [8]. This artifact's use of metaphor builds an argumentative case for freedom, justice, and empathy. The following analysis will shed light on how authentic slave testimony, metaphor, symbolism, personification, and juxtapositions, once coded, can bring us to a reality that may not seem so unfamiliar in comparison to our current climate of racial social instability which has erupted in an uproar of protests, movements such as Black Lives Matter, as well as a full-blown unravelling social awakening.
\end{abstract}

Keywords - African-American identity, Antebellum slavery, Lewis Richardson, metaphor, speech.

SUGGESTED CITATION: Mohammed, S. (2021). The promotion of social awakening through the speech of Lewis Richardson: A Metaphorical Lens that is Echoed Today. Proceedings of the International Crisis and Risk Communication Conference, Volume 4 (pp. 72-75). Orlando Fl: Nicholson School of Communication and Media. https://doi.org/10.30658/icrcc.2021.18

\section{INTRODUCTION}

Our American history is not perfect. We as a nation can learn a great deal from history and bring those life lessons to the surface to our advantage present-day. Slave testimony gave us insight on how the history of racism was born. As Douglass put it, "they divided both to conquer each" [7]. Fredrick Douglas, as well as many other people of African descent began to express their significant concerns to the public by the means of rhetorical discourse in attempt to invoke social change. "Metaphors figure in a central and ineliminable way in the construction and evaluation of scientific explanations" [2]. Kenneth Burke takes a similar view, suggesting that metaphor plays a critical role "in the discovery and description of truth." [8]. The research questions that will be the focal point of this study centers around the following inquiries: RQ-Are there similar patterns one can detect between accounts, imagery, and representation of slave testimony from the past and modern-day projections of social instability? Can we extract parallels from metaphoric critical devices that have been embedded in reflective historic rhetoric with modern day rhetorical devices, events of racial friction, and social instability? Can the deconstruction of constructed metaphoric rhetorical devices from our past act as a key that unlocks a means to reading, interpreting, and evaluating social influences that may transcend the dials of time? "Shifting metaphors means changing perspectives - making new connections and seeing in new ways - for both the creator of and the audience for the metaphor" [8].This study demonstrates the significant relevance of how metaphoric rhetorical devices were founded in a period of time such as the 1800's in comparison to modern day rhetorical devices that may act as catalysts for racial injustice, social inequities, and social interpersonal communication.

\section{CONTEXT \& INTERPERTATION}

The artifact this study dismembers a speech that was delivered by Richardson in 1846. A few years after his speech Clay was recognized for unexpected shifts in his actions as, on January 29 1850, Kentucky senator Henry Clay proposed a set 
of resolutions to appease the interests of the North and South [10]. After a lifetime of slavery, being owned by politician Richardson, as well as many others, characterized the roles of Griots. "Validating self means rhetorically reconstructing the past in the legacy of the African "griot." "Griot" symbolizes in African oral tradition the ethical responsibility one has as a "keeper of the culture" [5]. Griots of West African traditional society were usually known to be male performing in the courts praising royal lineage. In the light of rhetorical substance painting reflective images of our reality, the speech speaks volumes in the magnification of Richardson's story with use of numerous metaphoric rhetorical devices that provide not only historical insight, but also transcends our own scope of reality. Richardson symbolizes the rhetor in his action of connecting the dots for the audience, explaining patterns, and using rhetorical tools such as juxtapositions and metaphor to paint the whole picture for the audience to see through his design of metaphoric symbolism in rhetoric.

\section{METAPHORICAL CRITICISM}

Among a plethora of metaphor Richardson employs, this analysis revolves around a selected balance of data collected that fit the realm of metaphoric criticism. "Rhetorical discourse (in the forms of oral histories, magazines, newspapers, radio broadcasts, speeches, sermons, and barroom and barbershop interpersonal contact) created the ideas, images, and narratives, through which southern blacks constructed alternative dreams, dreams whose mythic promises of a better life provided just such motivations" (Desantis, 1998, p.476). The lecture circuit of speeches did not only represent discourse, but also gave the speakers as well as listeners hope for a better future for them and their families. Their hopes and dreams were literally wrapped up in their story's incarnation of metaphor. In existing fused images of tenor and vehicle, chosen vehicles support the tenor that represents the concept of how life as an enslaved human, acts like a cushion for racial injustice to thrive in. In the field of vehicles capitalizing on this tenor, we find symbols of human despair, sacrifice, hopelessness, bondage, the erosion of family units, hope in the future, and freedom. "Style and character, audience and ideology, are intertwined in a tapestry of symbolic meaning" [10]. According to Kurtz, the use of metaphor can carry multiple characteristics that assist in creating meaning. These vehicles help mobilize the represented tenor of racial injustice. Vehicles employ the assembling of a fuller picture for the audience to visualize through vivid imagery.

As Richardson begins his speech, he expresses gratitude for being a free man in addressing the audience. "Even though slavery as an economic system is found throughout human history, capitalism commodified and racialized it for profit"'[7]. Richardson was seen as property, a commodity that was owned by Henry Clay for many years. He describes being whipped by Clay one hundred fifty lashes for not making back before 5:00 from visiting his wife. Richardson uses the concept of the "parting hand" as he describes himself escaping to Canada as he was forced to leave his wife behind. Imagery is operated in the projecting form of eroding family units. Having no choice, leaving his wife behind was his only regret. The controversial Fugitive Slave Law was established in response to trying to decrease the number of slaves that may attempt to escape the Southern states to the Northern states for the purpose of living a better life.

Richardson proceeds explaining what he expected in his use of metaphor in being, "pursued as a felon" [1]. This image produced by metaphor is profound and still carries a significant amount of weight in American society today, centuries later. A human being, that just happens to be of African American descent, was widely accepted as existing as the property of others; to the extent of enduring the possibility of being branded as it was not a foreign concept at that time. A felon is a person that is running from persecution after committing crimes. "The rhetor wanting to shape the judgments of the audience must present with clarity the questions around which a crisis center" [10]. Richardson's only crime was that he was born with black skin. Richardson was a human being that wanted to be free. "Self-responsibility serves to support the work of equity by finding agency within oneself, cultivating the desire to examine one's role in the suppression of equality, and having the need to see oneself and others on the level with others" [6]. In Richardson focusing on self-responsibility, we can also locate and use the energy of equality to promote equality and equity for others in today's society by inducing self-responsibility. Also, this preconceived interpretation, perception, and image runs parallel with present cases of people of African American descent being seen, understood, and perceived in a similar manner. "Advocating Black empowerment and race consciousness, their rhetoric materialized into a feasible channel for group representation among Blacks" [9]. Group representation became more and more prominent in 2020 as a result of the many tragic events that transpired. We can apply these concepts to the case of George Floyd's murder. Derek Chauvin saw Floyd through a similar lens and therefore did not place value to his life. Floyd was not guilty of a crime, but could not escape being seen as less than human, ill-treatment, and being perceived as a felon due to the mere color of his skin. It becomes clear that the accounts of Richardson and Floyd found common place, intersecting dials of time and space.

Richardson employs another metaphor that supports this connection. He continues describing the expectation of being, "hunted as a fox from mountain to cave" [1], as he attempts to escapes slavery. The symbolism behind being hunted as a fox carries multiple layers to unpack. In transition from our discussion, the image of the fox amplifying the concept of Richardson not being seen, treated, or considered as a human being carries additional significant properties. The other part of this image employs the fox being hunted. Moving past Richardson's surface description, it is vital to acknowledge what runaway slaves, enslaved human beings, felt as they were being hunted down. Through Richardson's vivid use of imagery, he invokes a clear description of feeling emotionally disconnected with any ounce of his humanity. He uses his human emotions to paint the metaphoric image of the fox. Condit addresses this element in detail; "If humans 
are desirably and inherently emotional beings, and also inherently and desirably social beings, then it may be preferable that our construction of shared emotion be deliberate rather than unreflective"[4]. As the audience listened to Richardson's speech, the fox metaphor could've been translated into a shared, collective means of genuinely understanding the level of inhumanity one may feel as they are being chased down like an animal, like a fox. Again, we witness continuous patterns that have been interwoven into historical accounts and images of people of African American descent being understood as carrying less than human status, seen as animals. Richardson's speech offers us a great example of ideas he's produced to tell his story and mobilize social mobility then and now. This theme, concept, and reality remains relevant to many tragic events that have unraveled in 2020. "Crisis provides the vortex in which the character, words, and actions of public figures may be judged" [10]. In the delivery of his speech and his employment of metaphor, Richardson was vulnerable and his audience felt the genuine nature and substance of his experiences. We have witnessed countless senseless deaths of people of African American descent rapidly rise and further mobilize movements such as Black Lives Matter. "This comparative view thus awakens us to an apparent irony within the political traditions that the United States best exemplifies.” (Matory, 2007, p. 399) From 1846 to 2020, the question of placing value to human life when it comes to people of African American descent remains distorted, scarred, and fractured.

Richardson refused to surrender to a dooming fate and fought to gain his freedom to live as a free man. In Richardson's escape from slavery he travelled from Kentucky to Canada. He describes a juxtaposed image that illustrates country borders in alignment with each geographical location's regulations and laws surrounding the meaning of the bondage of slavery versus freedom. "Such usage as this caused me to flee from under the American eagle, and take shelter under the British crown" [1]. Richardson explicitly describes geographical space separately by each nation's patriotic icons. Clusters of social networks became sources of motivation, security, and community for people of African American descent to turn to. He explains an association with the United States national symbol of the American Eagle with representing bondage, an inhumane reality, racial injustices, and captivity. This concept is juxtaposed with the shelter of the British Crown, which at that time represented the geographical space of Canada. From his perspective, he illustrates that Canada represented, shelter, freedom, protection, safety, and glimpses of humanity in his description. In his illustration of what each country symbolized, the audience probably heard and felt the friction between both realities for people of African American descent; a friction that set the tone for two separate worlds they experienced from behind the borders of geography and space. Matory signifies that there is a cross-cultural encounter that builds division by classifying the nature of the Other as less than according the cultural, geographical, and moral standards. Richardson recognizes and acknowledges what each country represents from an African American perspective and brutal realities of that time. One can compare what Americans faced at the height of the Civil War. A human being's status, to live free or to live as a slave, was determined by geography. Geography unapologetically housed marks of systematic oppression. Systematic oppression that translates into inequities our society still endures in 2020.

The pattern of symbols Richardson employs in his speech continues, he draws contrast between slavery and liberty. After entering two distinct worlds, he is able to address the juxtaposition between the meaning surrounding the truths of slavery and liberty. "Oh, what a contrast between slavery and liberty! Here I stand erect, without a chain upon my limbs" [1]. In liberty, he stands erect. He is able to stand. Standing on one's own symbolized endorsing independence, individuality, and pride. In slavery, there are images of racial subjugation to bondage, inhumanity, torture, oppression and human degradation. "But perhaps we may assent that moral judgments, carefully rendered, weighed against the context out of which a discourse emerged and to which it spoke, may foster a criticism that not only illuminates rhetorical action, but also orders our intellectual and ethical commitments" [10]. The audience's moral and ethical judgment gets put to the test in the process of listening to the accounts driven by slavery. Slavery locked him in chains upon his limbs, not allowing him to, metaphorically stand and be independent keep his head up and exist as human. The chains he describes connect with systematic inequities people of African American descent are still forced to endure without relief or release in higher quantities in a post pandemic 2020 era.

The final rhetorical instrument to dismantle lies in Richardson's note of gratitude, "Thanks be to God that I am elected to Canada, and if I don't live but one night, I am determined to die on free soil. Let my days be few or many, let me die sooner or later, my grave shall be made in free soil" [1]. In his psychological inner negotiations with meeting a foreseen death, he had settled a bargain that determined a craving for freedom even in death. "Equally persuasive is the allied view that 'resistance' and the pursuit of 'freedom' have been the founding principles and enduring essence of black New World identities." (Matory, 2007, p. 420) Black identities are negotiated upon and fought for as if black identity did not belong to them, but was owned by someone outside of themselves. In his mind it wasn't a matter of when he would meet death, but more of a matter of where. Again, we see geography defining the value of his life in both arenas of life and in death. "Although there has been a remarkable improvement in race relations and the invidious representations of African Americans in America's dominant media formations, the "othering” of African Americans hasn't waned. Whatever improvements have been witnessed over the last few decades have been undermined by "backlashes, unsettling patterns of benign neglect, and new, subtler forms of racial hostility"[7]. Many Americans may pass most of their lifetimes without carrying such a heavy burden. This weight that carries instabilities in psychological, mental, and fractured identities remain hazardous implications and risks on human lives regardless of the color of their skin and origin. Why is this significant? Year 2020 has surfaced such patterns. Families of African American descent across our country understand this concept with clarity. Parents have been inclined, forced, and felt obligated to sit down with their 
children to talk to them about the threats, risks, and life-threatening oppression our society has on the integrity of their lives as African American youth.

It is my hope that through this analysis people can begin to shed a light of understanding on the link between the historical foundational standards of slavery and how the residual impact of those tragic events still resides in the aftershocks of lingering social injustices that have surfaced in the year 2020. Richardson made a choice to explore selfresponsibility. Alfred Alder, a psychologist, emphasized the need to understand individuals within their social context. In the early $19^{\text {th }}$ century, Alder began exploring current matters such as equality, lifestyle, and the holism of individuals. "Self-responsibility is closely linked with Adler's declarations of three essential human needs for human development: (a) to be safe, as in "I am safe with me, I am safe with you, I am safe in this place"; (b) to belong, as in "I belong here, these are my people, my contribution is valued, I feel part of humanity"; (c) to be significant, as in "I matter, I count, what I contribute matters" [6]. Alder believed that we all have the basic desire and goal of wanting to belong and matter. This analysis is an anthem to the nature of the collision in these concepts. As scholars, and through our social relationships and interactions, we practice our capability for self-responsibility. In facing social challenges such as racism, our unconscious bias, and our distorted beliefs, each individual has the opportunity to create inclusive and equitable living conditions by not ignoring existing inequities and social injustice. There are American families that exist deprived of enjoying the nature of freedom in its fullest capacity on American, free soil.

\section{CONCLUSION}

In the mist of theoretical metaphoric rhetorical criticism, lies messaging, messages that can even address an urgency in matters of life and death. "This notion of a rhetoric of humanity underscores an African cosmology of harmony and time" [5]. Richardson sent us an SOS message interwoven in metaphor that has travelled in time and space as it transcends the dials of time. "Perhaps we might celebrate the chance to participate together in that exploration, even as we struggle to share good judgments about our social history more broadly"[4]. Many of the concepts, interpretations, and reflections projected in this analysis are common place before and after the borders of 2020. "Systems of domination, such as racism, naturalize and reproduce themselves through what is written and said, and this fact justifies the choice of discourse analysis as the methodological apparatus of choice to make this visible." [7]. As this channel dismantles metaphoric rhetoric, it unveils how Richardson's speech communicates his battle between consequences he lived in slavery versus freedom. Richardson's speech was a cry for help that is still heard as it echoes in installments of moments in time. "As the accounts become more secure, the metaphors may become less visible, but they do not disappear"'[2]. This analysis magnifies how metaphoric rhetoric is capable of dismantling truths that can be given a pulse, brought to life, and serve as keys that can unlock patterns of symbols and meaning that may travel and unravel across intersections of time and space.

\section{Author Biography}

Suha Mohammed is a Doctoral student at Regent University, M.A. Governors State University, suha_sjm@yahoo.com. The full version of this article will be published in the Texas Journal of Speech Communication, Volume 45, Issue 1.

\section{REFERENCES}

[1] Blassingame, J. W. (2009). Slave testimony: two centuries of letters, speeches, interviews, and autobiographies. Louisiana State University Press.

[2] Bradie, M. (1998). Explanation as metaphorical redescription. Metaphor and Symbol, 13(2), 125-139. https://doi.org/10.1207/s15327868ms302_3

[3] Brock, K. (2019). Rhetorical Code Studies: Discovering Arguments in and around Code. http://www.jstor.org/stable/10.2307/j.ctvndv9pc?refreqid=search-gateway:b7ce853ee52f90989a726b8b26fbbb81

[4] Condit, C. M. (2013). Pathos in Criticism: Edwin Black's Communism-As-Cancer Metaphor. Quarterly Journal of Speech, 99(1), 1-26. https://doi.org/10.1080/00335630.2012.749417

[5] Davis, O. I. (1998). A black woman as rhetorical critic: Validating self and violating the space of otherness. Women's Studies in Communication, 21(1), 77-90. https://doi.org/10.1080/07491409.1998.10162414

[6] Day, C. R. (2018). A Case Study: Claiming Equity Using Early Story and Metaphor. The Journal of Individual Psychology, 74(1), 55-74. https://doi.org/10.1353/jip.2018.0004

[7] Fabregat, E., \& Kperogi, F. A. (2019). White norm, Black deviation: Class, Race, and Resistance in America's "Postracial" media discourse. Howard Journal of Communications, 30(3), 265-283. https://doi.org/10.1080/10646175.2019.1491433

[8] Foss, S. K. (2018). Rhetorical criticism: Exploration and practice. Long Grove, IL: Waveland Press.

[9] Harrell, W. J. (2006). A Call to Consciousness and Action: Mapping the African-American Jeremiad. Canadian Review of American Studies, 36(2), 149-180. https://doi.org/10.1353/crv.2006.0042

[10] Kurtz, J. B. (2001). Condemning Webster: Judgment and audience in Emerson's 'fugitive slave law'. Quarterly Journal of Speech, 87(3), 278-290. https://doi.org/10.1080/00335630109384337 